\title{
Identification of biological processes and signaling pathways in lactate-treated cancer cells
}

Zhiwen Qian, Hanming Gu, Tingxiang Chang ${ }^{1}$

${ }^{1}$ SHU-UTS SILC School, Shanghai University, Shanghai, China

"Corresponding author: Hanming Gu, SHU-UTS SILC School, Shanghai University, Shanghai, China

laygmp@gmail.com 


\section{Abstract}

Cancer is a complex disease that involves the alterations of metabolic pathways and tumor microenvironment. Lactate in the tumor microenvironment leads to cancer proliferation, metastasis, and angiogenesis. However, the effect of lactate on prostate cancer cells is still unclear. Here, our objective is to identify the significant molecules and biological processes by analyzing the RNA-seq data. The GSE195639 was produced by the Illumina NextSeq 500 (Homo sapiens). The KEGG and GO analyses show that Herpes simplex virus 1 infection and Rap1 signaling pathway are considered major pathways during the lactate-treated cancer cells. Furthermore, we identified the top ten essential molecules including IL6, CASP3, JUN, MAPK3, BRCA1, PIK3R1, CCNA2, TPI1, APOE, and EXO1. Therefore, our study may provide novel insights into the mechanism of prostate cancers.

\section{Introduction}

Prostate cancer is hard to cure due to the complexity of molecular and cellular heterogeneity ${ }^{1}$. In the USA, high-risk disease contains $15 \%$ of all prostate cancer diagnoses $^{2}$. Despite a decreasing death rate over the past 10 years, prostate cancer (PCa) remains the most dominant male malignancy worldwide ${ }^{3}$. Therefore, to meet this clinical need and provide effective treatment methods, it is of utmost importance to study the impact of the tumor microenvironment (TME) ${ }^{4}$.

Lactate was recently identified as a fuel by cancer cells under complete aerobic conditions $^{5}$. Surprisingly, it was shown that lactate resides inside the mitochondria and synthesizes lipids by cancer cells ${ }^{6}$. Moreover, LDHB is localized in the inner mitochondrial membrane and was related to the mitochondrial functions ${ }^{7}$. Thus, lactate is considered to be oxidized to pyruvate in the mitochondria by $\mathrm{LDHB}^{8}$. Lactate itself cannot transfer the plasma membrane, so it requires a unique transport mechanism provided by proton-like MCTs ${ }^{5}$. It was also found that lactate shuttle is promoted by $\mathrm{pH}$ gradient or by the cellular redox state ${ }^{9}$. The tumor microenvironment includes cancer cells, endothelial cells, cancer-associated fibroblasts, and immune cells ${ }^{10}$. During tumor initiation, neoplastic cells recruit cancer-associated fibroblasts to surround the area through the oxidative stress ${ }^{11}$. 
In this study, we identified the signaling pathways of lactate-treated cancer cells by using the RNA sequence data. There were several DEGs, signaling pathways, and protein-protein interaction (PPI) networks identified. The DEGs and PPI networks may guide the treatment of prostate cancer by targeting the tumor microenvironment.

\section{Methods}

Data resources

Gene dataset GSE195639 was collected from the GEO database. The data was produced by the Illumina NextSeq 500 (Homo sapiens) (The Institute of Oncology Research, Via Vela 6, Bellinzona, Switzerland). The analyzed dataset includes muscles treated by 4 groups of control prostate cancer cells and 4 groups of lactate-treated prostate cancer cells.

Data acquisition and processing

The data were conducted by the $R$ package as previously described ${ }^{12-17}$. We used a classical t-test to identify DEGs with $\mathrm{P}<0.05$ and fold change $\geq 1.5$ as being statistically significant.

The Kyoto Encyclopedia of Genes and Genomes (KEGG) and Gene Ontology (GO)

KEGG and $\mathrm{GO}$ analyses were performed by the $\mathrm{R}$ package (clusterProfiler) and Reactome. $\mathrm{P}<0.05$ was considered statistically significant.

Protein-protein interaction (PPI) networks

The Molecular Complex Detection (MCODE) was used to construct the PPI networks. The significant modules were produced from constructed PPI networks and String networks. The signaling pathway analyses were performed by using Reactome (https://reactome.org/), and $\mathrm{P}<0.05$ was considered significant.

\section{Results}

Identification of DEGs between the prostate cancer cells and lactate-treated prostate cancer cells 
To study the impact of lactate on prostate cancer cells, we analyzed the RNA-seq data from the prostate cancer cells treated by lactate. A total of 1351 genes were identified with the threshold of $P<0.01$. The top up- and down-regulated genes in the lactatetreated prostate cancer cells were identified by the heatmap and volcano plot (Figure 1). The top ten DEGs were listed in Table 1.

\section{Enrichment analysis of DEGs between the prostate cancer cells and lactate- treated prostate cancer cells}

To further determine the potential molecular mechanisms, we performed the KEGG and GO analyses (Figure 2). We identified the top ten KEGG signaling pathways, including "Herpes simplex virus 1 infection", "Rap1 signaling pathway", "Biosynthesis of amino acids", "VEGF signaling pathway", "Fructose and mannose metabolism", "Amino sugar and nucleotide sugar metabolism", "Galactose metabolism", "Biosynthesis of nucleotide sugars", "Glycosaminoglycan biosynthesis - chondroitin sulfate / dermatan sulfate", and "Terpenoid backbone biosynthesis". We also identified the top ten biological progresses of GO, including "nucleoside phosphate metabolic process", "hexose metabolic process", "monosaccharide metabolic process", "maintenance of location in cell", "nucleoside diphosphate metabolic process", "nucleotide phosphorylation", "maintenance of protein location in cell", "release of cytochrome c from mitochondria", "hexose catabolic process", and "positive regulation of endothelial cell chemotaxis". We identified the top ten cellular components, including "mitochondrial matrix", "intrinsic component of organelle membrane", "integral component of organelle membrane", "endoplasmic reticulum lumen", "lysosomal lumen", "lumenal side of membrane", "MHC protein complex", "integral component of lumenal side of endoplasmic reticulum membrane", "lumenal side of endoplasmic reticulum membrane", and "synaptic cleft". We also identified the top ten molecular functions of GO, including "isomerase activity", "dioxygenase activity", "pentosyltransferase activity", "ligand-gated calcium channel activity", "carbohydrate kinase activity", "calcium-release channel activity", "UDP-xylosyltransferase activity", "xylosyltransferase activity", "DNA-(apurinic or apyrimidinic site) endonuclease activity", and "peptidyl-proline dioxygenase activity". 


\section{Construction of PPI network based on the identified DEGs}

To understand the potential relationships between the identified DEGs, we created the PPI network by the Cytoscope software. The combined score $>0.2$ was set as a cutoff by linking the 108 nodes and 93 edges. Table 2 demonstrated the top ten genes with the highest degree scores. The top two clusters were shown in Figure 3. We further evaluated the DEGs and PPI by Reactome map (Figure 4) and figured out the top ten significant biological processes including "Antigen Presentation: Folding, assembly and peptide loading of class I MHC", "Endosomal/Vacuolar pathway", "ER-Phagosome pathway", "Antigen processing-Cross presentation", "Interferon gamma signaling", "Interferon alpha/beta signaling", "Interferon Signaling", "Immunoregulatory interactions between a Lymphoid and a non-Lymphoid cell", "Class I MHC mediated antigen processing \& presentation", and "PD-1 signaling" (Supplemental Table S1).

\section{Discussion}

Tumor cells can convert pyruvate into lactate even under normal conditions ${ }^{18}$. Metabolic alterations of tumor cells change the metabolic fluxes, Krebs cycle, and glycolysis, which results in the production of high amounts of lactic acid $^{19}$. The tumor cells can have more lactic acid than normal cells ${ }^{20}$. Thus, understanding the effect of lactate on cancer cells is key to the development of effective therapies.

In this study, Herpes simplex virus 1 infection and Rap1 signaling pathway were considered major pathways during the lactate-treated cancer cells. Oncolytic viruses such as herpes simplex virus type 1 (HSV-1) replicate in tumors and increase immunogenic cell death and induction of immunity ${ }^{21}$. The HSV-1 infection was shown most effective in combination with other anti-cancer agents such as PD1/L1 related immunity $^{22}$. Our study showed that prostate cancer has the same phenotype as HSV-1 infection, suggesting that lactate may also activate cell death or immunity to limit cancer cells $^{23}$. Numerous signaling pathways regulate the activities of G-protein-coupled receptors (GPCRs) ${ }^{24-26}$. GPCRs and Regulators of G protein signaling (RGS) proteins form a feedback loop to mediate the downstream molecules and signaling pathways ${ }^{27-36}$. Among them, GTPase plays different roles in proliferative responses by targeting GPCRs $^{37}$. Rap1 has a similar sequence to Ras, which regulates cell adhesion and 
integrin function in a variety of cells ${ }^{38}$. Specifically, Rap1 initiates ERK signaling that is activated in many malignancies and is an effective target of cancers ${ }^{39}$.

In addition, we also discovered the top ten interaction molecules by constructing the PPI network. Takuji Hayashi et al. found that the high-fat diet can induce inflammation and promote prostate cancer growth through IL6/pSTAT3 signaling in the mice ${ }^{40}$. Circadian clocks regulate a variety of biological processes including inflammation, metabolism and aging $^{41-51}$. I Aiello et al. found that the disruption of circadian clock can affect the IL6 expression and change the tumor state ${ }^{52}$. Shu-Pin Huang and Chun-Hsiung Huang et al. found that the genetic variants in CASP3 may affect the survival in prostate cancer patients receiving androgen-deprivation therapy by analyzing several genome-wide association studies (GWAS) ${ }^{53}$. Christine Moore demonstrated that the upregulation of JUN is critical to the differential effect on apoptosis in prostate cancer cells ${ }^{54}$. Rong Deng et al. found that MAPK1 mediates the ULK1 degradation to decrease mitophagy and promotes cancer cell metastasis ${ }^{55}$. Genomic analysis indicates BRC1 is strongly associated with prostate cancer risk and aggressiveness ${ }^{56}$. PI3K regulatory subunit gene PI3K1 is inhibited in prostate cancers ${ }^{57}$. Weighted gene co-expression network indicates CCNA2 is a potential therapeutic target for prostate cancer by inhibiting cell cycle $^{58}$. TPI1 is associated with the tumor microenvironment and squamous cell cancer $^{59}$. APOE polymorphism affects aggressive behavior in prostate cancer cells by inhibiting cholesterol homeostasis ${ }^{60}$. Fei Luo and Kuo Yang et al. found the expression of EXO1 is related to clinical progression, metastasis, and survival prognosis of prostate cancer $^{61}$.

In conclusion, this study discovered the biological functions of lactate in prostate cancer cells. Herpes simplex virus 1 infection signaling and Rap1 signaling pathway are the major pathways during the lactate-treated cancer cells. Our study may help to shed light on the mechanism of tumor metabolism.

\section{Author Contributions}

Zhiwen Qian, Tingxiang Chang: Methodology. Hanming Gu: Conceptualization, Writing and Editing. 
bioRxiv preprint doi: https://doi.org/10.1101/2022.02 16.480756; this version posted February 19,2022 . The copyright holder for this preprint

(which was not certified by peer review) is the author/funder, who has granted bioRxiv a license to display the preprint in perpetuity. It is made available under aCC-BY-NC-ND 4.0 International license.

\section{Funding}

This work was not supported by any funding.

\section{Declarations of interest}

There is no conflict of interest to declare. 

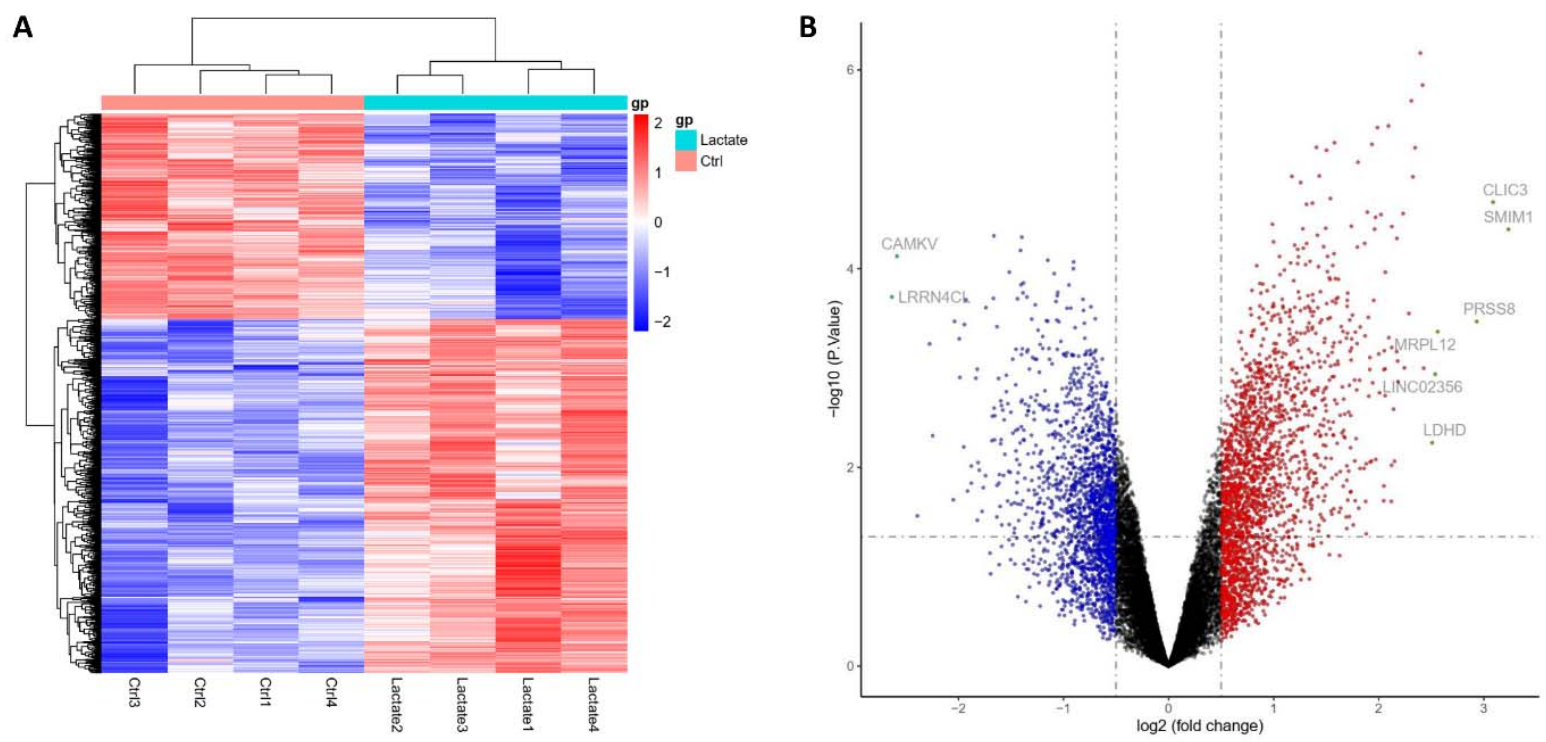

Figure 1. Heatmap and volcano plot were created between the prostate cancer cells and lactate-treated prostate cancer cells

(A) Significant DEGs $(P<0.01)$ were used to produce the heatmap.

(B) Volcano plot for DEGs between the prostate cancer cells and lactate-treated prostate cancer cells. The most significantly changed genes are highlighted by grey dots. 
A

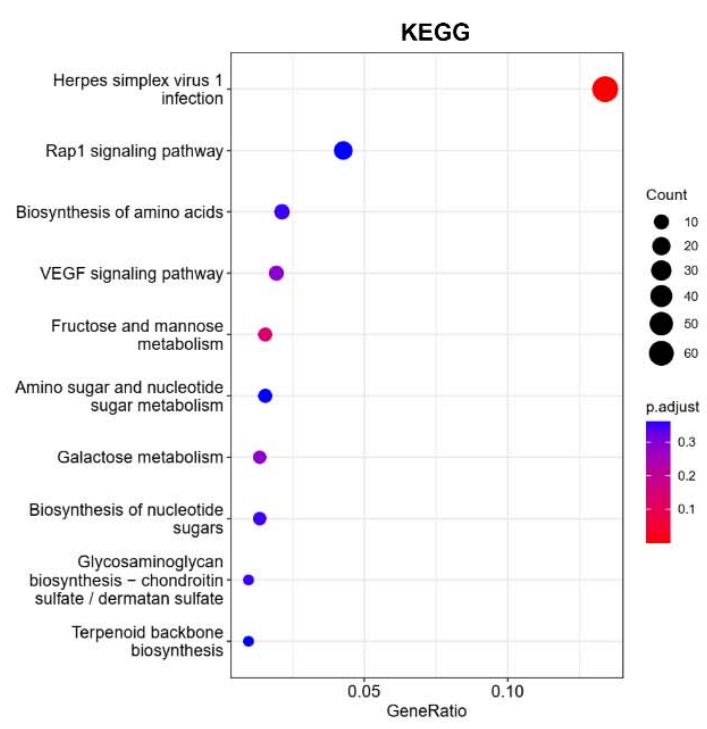

C

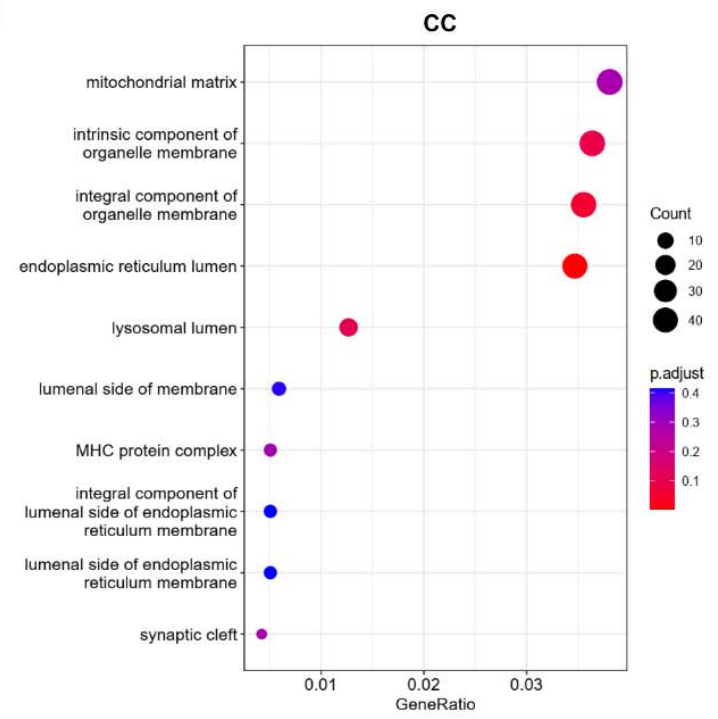

B

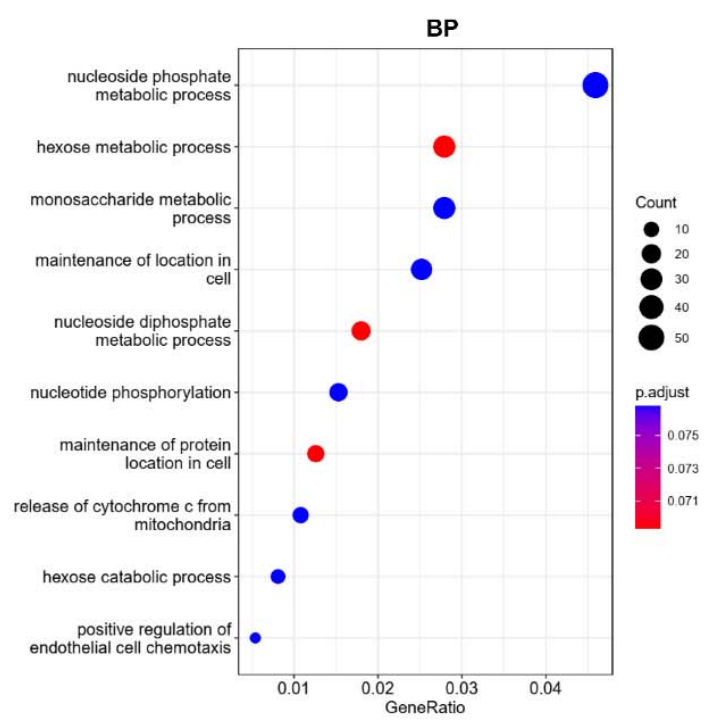

D

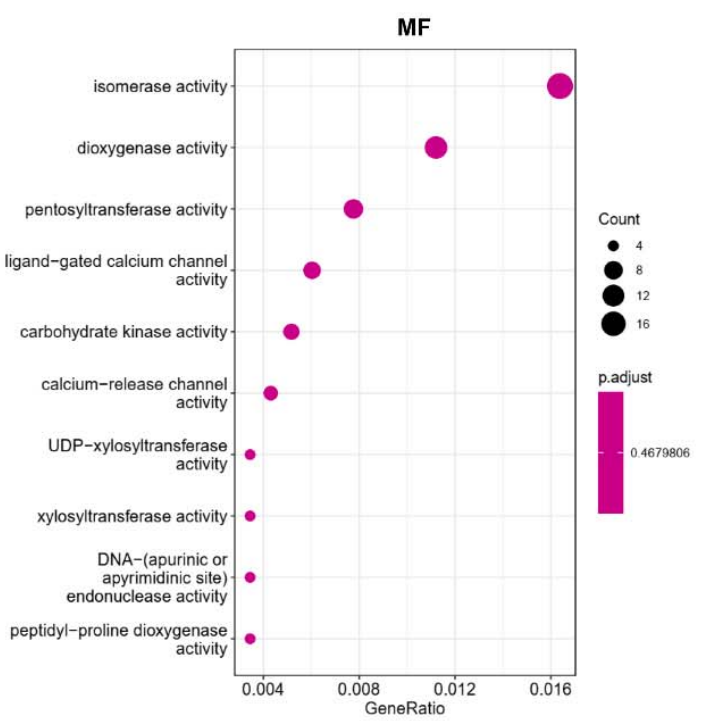

Figure 2. KEGG and GO analyses of DEGs between the prostate cancer cells and lactate-treated prostate cancer cells

(A) KEGG analysis, (B) Biological processes, (C) Cellular components, (D) Molecular functions. 
A

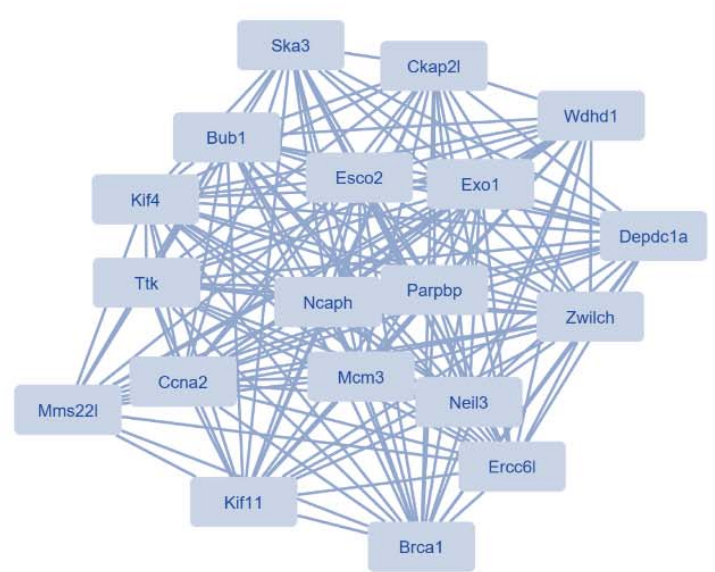

B

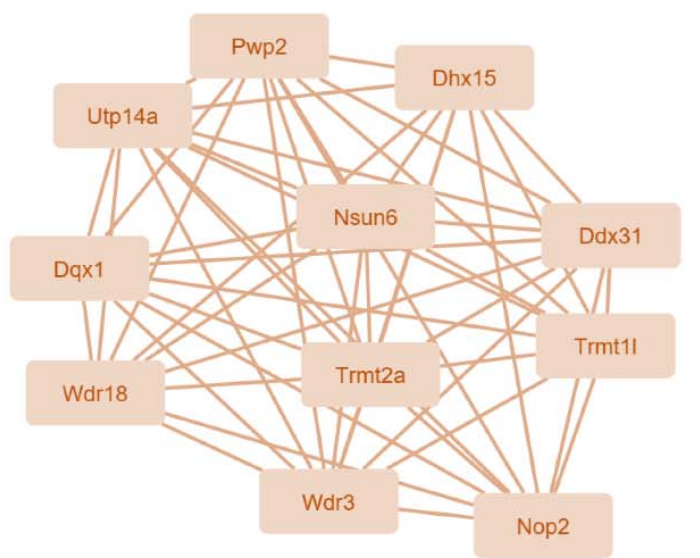

Figure 3. The PPI network analyses of DEGs between the prostate cancer cells and lactate-treated prostate cancer cells

The cluster $(A)$ and cluster $(B)$ were constructed by MCODE. 
bioRxiv preprint doi: https://doi org/10.1101/2022 02.16 480756; this version posted February 19,2022 . The copyright holder for this preprint (which was not certified by peer review) is the author/funder, who has granted bioRxiv a license to display the preprint in perpetuity. It is made available under aCC-BY-NC-ND 4.0 International license.

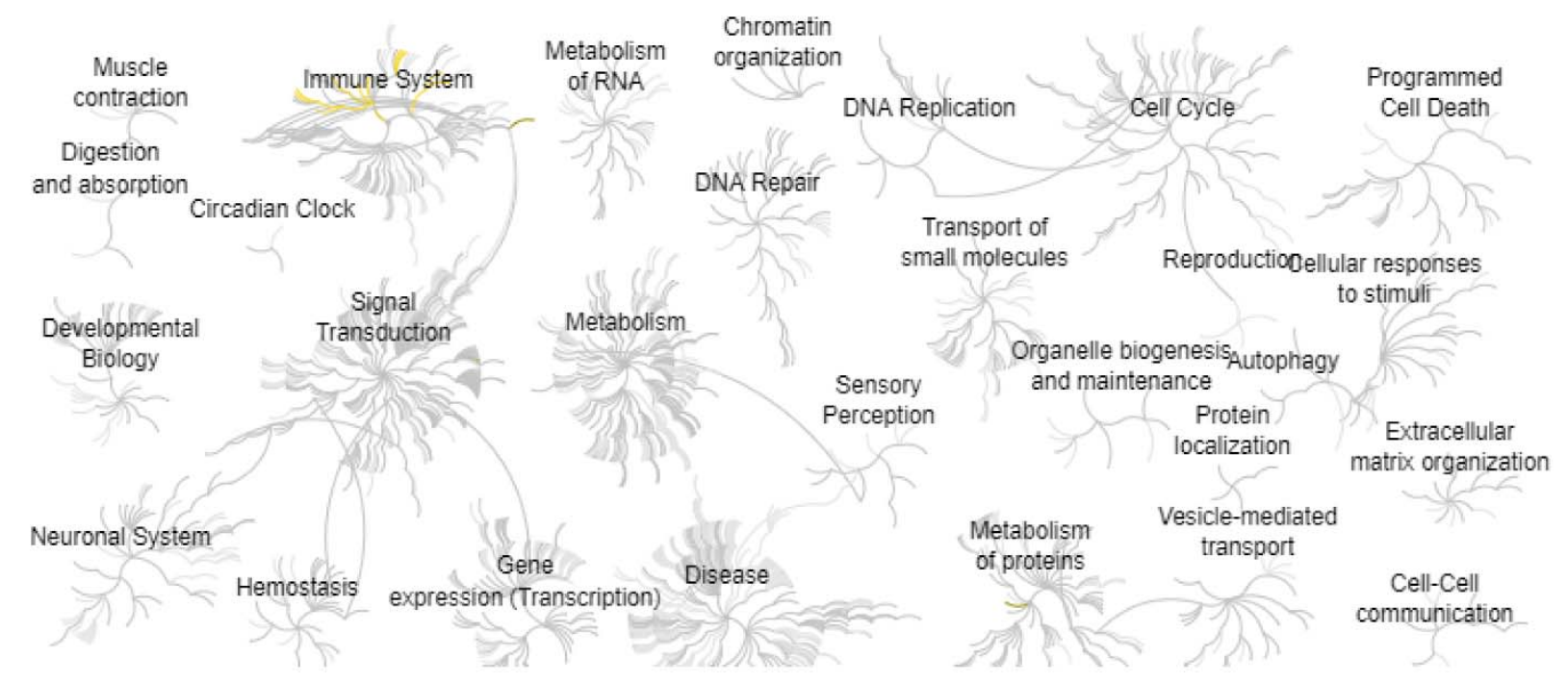

Figure 4. Reactome map representation of the significant biological processes between the prostate cancer cells and lactate-treated prostate cancer cells 


\section{Table 1}

\begin{tabular}{llll}
\hline Entrez gene & Gene symbol & Fold-change & Regulation \\
\hline \multicolumn{1}{l}{ Top 10 down-regulated DEGs } & & \\
221091 & LRRN4CL & -2.633055773 & Down \\
79012 & CAMKV & -2.585151569 & Down \\
140862 & ISM1 & -2.274053106 & Down \\
1270 & CNTF & -2.245772454 & Down \\
10888 & GPR83 & -2.037045662 & Down \\
10936 & GPR75 & -1.99194638 & Down \\
79844 & ZDHHC11 & -1.986611188 & Down \\
170559 & XPOTP1 & -1.948959541 & Down \\
84519 & ACRBP & -1.943106017 & Down \\
3798 & KIF5A & -1.928236896 & Down \\
Top 10 up-regulated DEGs & & \\
388588 & SMIM1 & 3.233398414 & up \\
9022 & CLIC3 & 3.087748155 & up \\
5652 & PRSS8 & 2.932441918 & up \\
6182 & MRPL12 & 2.560255659 & up \\
105369984 & LINC02356 & 2.536982989 & up \\
197257 & LDHD & 2.509296957 & up \\
136259 & KLF14 & 2.427548018 & up \\
6676 & SPAG4 & 2.417188052 & up \\
5745 & PTH1R & 2.396413295 & up \\
100506211 & MIR210HG & 2.345939024 & up \\
\hline
\end{tabular}


Table 2. Top ten genes demonstrated by connectivity degree in the PPI network

\begin{tabular}{lll}
\hline Gene symbol & Gene title & Degree \\
\hline IL6 & Interleukin 6 & 60 \\
CASP3 & Caspase 3 & 52 \\
JUN & Jun Proto-Oncogene, AP-1 Transcription & 51 \\
& Factor Subunit & \\
MAPK3 & Mitogen-Activated Protein Kinase 3 & 51 \\
BRCA1 & BRCA1 DNA Repair Associated & 50 \\
PIK3R1 & Phosphoinositide-3-Kinase Regulatory & 37 \\
& Subunit 1 & 37 \\
CCNA2 & Cyclin A2 & 36 \\
TPI1 & Triosephosphate Isomerase 11 & 35 \\
APOE & Apolipoprotein E & 34 \\
EXO1 & Exonuclease 1 \\
\hline
\end{tabular}




\section{References}

[1] Boyd LK, Mao X, Lu YJ: The complexity of prostate cancer: genomic alterations and heterogeneity. Nat Rev Urol 2012, 9:652-64.

[2] McKay RR, Feng FY, Wang AY, Wallis CJD, Moses KA: Recent Advances in the Management of HighRisk Localized Prostate Cancer: Local Therapy, Systemic Therapy, and Biomarkers to Guide Treatment Decisions. Am Soc Clin Oncol Educ Book 2020, 40:1-12.

[3] Rawla P: Epidemiology of Prostate Cancer. World J Oncol 2019, 10:63-89.

[4] Klemm F, Joyce JA: Microenvironmental regulation of therapeutic response in cancer. Trends Cell Biol 2015, 25:198-213.

[5] de la Cruz-Lopez KG, Castro-Munoz L, Reyes-Hernandez DO, Garcia-Carranca A, Manzo-Merino J: Lactate in the Regulation of Tumor Microenvironment and Therapeutic Approaches. Front Oncol 2019, 9:1143.

[6] San-Millan I, Brooks GA: Reexamining cancer metabolism: lactate production for carcinogenesis could be the purpose and explanation of the Warburg Effect. Carcinogenesis 2017, 38:119-33.

[7] Fan S, Wu K, Zhao M, Yuan J, Ma S, Zhu E, Chen Y, Ding H, Yi L, Chen J: LDHB inhibition induces mitophagy and facilitates the progression of CSFV infection. Autophagy 2021, 17:2305-24.

[8] Chen YJ, Mahieu NG, Huang X, Singh M, Crawford PA, Johnson SL, Gross RW, Schaefer J, Patti GJ: Lactate metabolism is associated with mammalian mitochondria. Nat Chem Biol 2016, 12:937-43.

[9] Brooks GA: The Science and Translation of Lactate Shuttle Theory. Cell Metab 2018, 27:757-85.

[10] Liu T, Zhou L, Li D, Andl T, Zhang Y: Cancer-Associated Fibroblasts Build and Secure the Tumor Microenvironment. Front Cell Dev Biol 2019, 7:60.

[11] Tao L, Huang G, Song H, Chen Y, Chen L: Cancer associated fibroblasts: An essential role in the tumor microenvironment. Oncol Lett 2017, 14:2611-20.

[12] Yu G, Wang LG, Han Y, He QY: clusterProfiler: an R package for comparing biological themes among gene clusters. OMICS 2012, 16:284-7.

[13] Hanming G: nuotrophils arthritis. Research Square 2021.

[14] Jing L, Letian W, Hanming G: Identification of driver genes and biological signaling for alcoholic myopathy. Research Square 2021.

[15] Li J, Wang W, Gu H: Identification of biological processes and signaling pathways for the knockout of REV-ERB in mouse brain. bioRxiv 2021:2021.11.22.469579.

[16] Yuan G: Identification of biomarkers and pathways of mitochondria in sepsis patients. bioRxiv 2021:2021.03.29.437586.

[17] $\mathrm{Gu} \mathrm{H}$ : Identification of biomarkers and pathways of mouse embryonic fibroblasts with the dysfunction of mitochondrial DNA. bioRxiv 2021:2021.04.05.438453.

[18] Liberti MV, Locasale JW: The Warburg Effect: How Does it Benefit Cancer Cells? Trends Biochem Sci 2016, 41:211-8.

[19] Romero-Garcia S, Lopez-Gonzalez JS, Baez-Viveros JL, Aguilar-Cazares D, Prado-Garcia H: Tumor cell metabolism: an integral view. Cancer Biol Ther 2011, 12:939-48.

[20] Choi SY, Collins CC, Gout PW, Wang Y: Cancer-generated lactic acid: a regulatory, immunosuppressive metabolite? J Pathol 2013, 230:350-5.

[21] Uche IK, Kousoulas KG, Rider PJF: The Effect of Herpes Simplex Virus-Type-1 (HSV-1) Oncolytic Immunotherapy on the Tumor Microenvironment. Viruses 2021, 13.

[22] Thomas S, Kuncheria L, Roulstone V, Kyula JN, Mansfield D, Bommareddy PK, Smith H, Kaufman HL, Harrington KJ, Coffin RS: Development of a new fusion-enhanced oncolytic immunotherapy platform based on herpes simplex virus type 1. J Immunother Cancer 2019, 7:214.

[23] Martuza RL: Conditionally replicating herpes vectors for cancer therapy. J Clin Invest 2000, 105:8416. 
[24] Billington CK, Penn RB: Signaling and regulation of G protein-coupled receptors in airway smooth muscle. Respir Res 2003, 4:2.

[25] Yuan G, Yang S, Yang S, Ng A, Oursler MJ: RGS12 is a critical proinflammatory factor in the pathogenesis of inflammatory arthritis via acting in Cox2-RGS12-NF kappa B pathway activation loop. J Bone Miner Res: WILEY 111 RIVER ST, HOBOKEN 07030-5774, NJ USA, 2019. pp. 147-.

[26] Yuan G, Yang S, Yang S: Macrophage RGS12 contributes to osteoarthritis pathogenesis through enhancing the ubiquitination. Genes \& Diseases 2021.

[27] Rosenbaum DM, Rasmussen SG, Kobilka BK: The structure and function of G-protein-coupled receptors. Nature 2009, 459:356-63.

[28] Yuan G, Yang S, Ng A, Fu C, Oursler MJ, Xing L, Yang S: RGS12 Is a Novel Critical NF-kappaB Activator in Inflammatory Arthritis. iScience 2020, 23:101172.

[29] Yuan G, Yang S, Gautam M, Luo W, Yang S: Macrophage regulator of G-protein signaling 12 contributes to inflammatory pain hypersensitivity. Ann Transl Med 2021, 9:448.

[30] Xie K, Martemyanov KA: Control of striatal signaling by g protein regulators. Front Neuroanat 2011, 5:49.

[31] Yuan G, Yang S, Liu M, Yang S: RGS12 is required for the maintenance of mitochondrial function during skeletal development. Cell Discov 2020, 6:59.

[32] Fu C, Yuan G, Yang ST, Zhang D, Yang S: RGS12 Represses Oral Cancer via the Phosphorylation and SUMOylation of PTEN. J Dent Res 2020:22034520972095.

[33] Stewart A, Fisher RA: Introduction: G Protein-coupled Receptors and RGS Proteins. Prog Mol Biol Transl Sci 2015, 133:1-11.

[34] Thirunavukkarasu K, Halladay DL, Miles RR, Geringer CD, Onyia JE: Analysis of regulator of G-protein signaling-2 (RGS-2) expression and function in osteoblastic cells. J Cell Biochem 2002, 85:837-50.

[35] Yuan G, Fu C, Yang ST, Yuh DY, Hajishengallis G, Yang S: RGS12 Drives Macrophage Activation and Osteoclastogenesis in Periodontitis. J Dent Res 2021:220345211045303.

[36] Yuan G, Huang Y, Yang ST, Ng A, Yang S: RGS12 inhibits the progression and metastasis of multiple myeloma by driving M1 macrophage polarization and activation in the bone marrow microenvironment. Cancer Commun (Lond) 2022, 42:60-4.

[37] Sun L, Ye RD: Role of G protein-coupled receptors in inflammation. Acta Pharmacol Sin 2012, 33:342-50.

[38] Bivona TG, Wiener HH, Ahearn IM, Silletti J, Chiu VK, Philips MR: Rap1 up-regulation and activation on plasma membrane regulates T cell adhesion. J Cell Biol 2004, 164:461-70.

[39] Shah S, Brock EJ, Ji K, Mattingly RR: Ras and Rap1: A tale of two GTPases. Semin Cancer Biol 2019, 54:29-39.

[40] Hayashi T, Fujita K, Nojima S, Hayashi Y, Nakano K, Ishizuya Y, Wang C, Yamamoto Y, Kinouchi T, Matsuzaki K, Jingushi K, Kato T, Kawashima A, Nagahara A, Ujike T, Uemura M, Pena M, Gordetsky JB, Morii E, Tsujikawa K, Netto GJ, Nonomura N: High-Fat Diet-Induced Inflammation Accelerates Prostate Cancer Growth via IL6 Signaling. Clin Cancer Res 2018, 24:4309-18.

[41] Fu L, Pelicano H, Liu J, Huang P, Lee C: The circadian gene Period2 plays an important role in tumor suppression and DNA damage response in vivo. Cell 2002, 111:41-50.

[42] Yuan G, Hua B, Cai T, Xu L, Li E, Huang Y, Sun N, Yan Z, Lu C, Qian R: Clock mediates liver senescence by controlling ER stress. Aging 2017, 9:2647-65.

[43] Zhu Z, Xu L, Cai T, Yuan G, Sun N, Lu C, Qian R: Clock represses preadipocytes adipogenesis via GILZ. J Cell Physiol 2018, 233:6028-40.

[44] Fan XF, Wang XR, Yuan GS, Wu DH, Hu LG, Xue F, Gong YS: [Effect of safflower injection on endoplasmic reticulum stress-induced apoptosts in rats with hypoxic pulmonary hypertension]. Zhongguo Ying Yong Sheng Li Xue Za Zhi 2012, 28:561-7. 
[45] Yuan G, Hua B, Yang Y, Xu L, Cai T, Sun N, Yan Z, Lu C, Qian R: The Circadian Gene Clock Regulates Bone Formation Via PDIA3. J Bone Miner Res 2017, 32:861-71.

[46] Zhu Z, Hua B, Shang Z, Yuan G, Xu L, Li E, Li X, Sun N, Yan Z, Qian R, Lu C: Altered Clock and Lipid Metabolism-Related Genes in Atherosclerotic Mice Kept with Abnormal Lighting Condition. Biomed Res Int 2016, 2016:5438589.

[47] Yuan G, Xu L, Cai T, Hua B, Sun N, Yan Z, Lu C, Qian R: Clock mutant promotes osteoarthritis by inhibiting the acetylation of NFkappaB. Osteoarthritis Cartilage 2019, 27:922-31.

[48] Xu L, Cheng Q, Hua B, Cai T, Lin J, Yuan G, Yan Z, Li X, Sun N, Lu C, Qian R: Circadian gene Clock regulates mitochondrial morphology and functions by posttranscriptional way. bioRxiv 2018:365452.

[49] Mao SZ, Fan XF, Xue F, Chen R, Chen XY, Yuan GS, Hu LG, Liu SF, Gong YS: Intermedin modulates hypoxic pulmonary vascular remodeling by inhibiting pulmonary artery smooth muscle cell proliferation. Pulm Pharmacol Ther 2014, 27:1-9.

[50] Zhu Z, Hua B, Xu L, Yuan G, Li E, Li X, Sun N, Yan Z, Lu C, Qian R: CLOCK promotes 3T3-L1 cell proliferation via Wnt signaling. IUBMB Life 2016, 68:557-68.

[51] Cai T, Hua B, Luo D, Xu L, Cheng Q, Yuan G, Yan Z, Sun N, Hua L, Lu C: The circadian protein CLOCK regulates cell metabolism via the mitochondrial carrier SLC25A10. Biochim Biophys Acta Mol Cell Res 2019, 1866:1310-21.

[52] Aiello I, Fedele MLM, Roman F, Marpegan L, Caldart C, Chiesa JJ, Golombek DA, Finkielstein CV, Paladino N: Circadian disruption promotes tumor-immune microenvironment remodeling favoring tumor cell proliferation. Sci Adv 2020, 6.

[53] Huang SP, Bao BY, Hour TC, Huang CY, Yu CC, Liu CC, Lee YC, Huang CN, Pao JB, Huang CH: Genetic variants in CASP3, BMP5, and IRS2 genes may influence survival in prostate cancer patients receiving androgen-deprivation therapy. PLoS ONE 2012, 7:e41219.

[54] Moore C, Palau VE, Mahboob R, Lightner J, Stone W, Krishnan K: Upregulation of pERK and c-JUN by gamma-tocotrienol and not alpha-tocopherol are essential to the differential effect on apoptosis in prostate cancer cells. BMC Cancer 2020, 20:428.

[55] Deng R, Zhang HL, Huang JH, Cai RZ, Wang Y, Chen YH, Hu BX, Ye ZP, Li ZL, Mai J, Huang Y, Li X, Peng XD, Feng GK, Li JD, Tang J, Zhu XF: MAPK1/3 kinase-dependent ULK1 degradation attenuates mitophagy and promotes breast cancer bone metastasis. Autophagy 2021, 17:3011-29.

[56] Patel VL, Busch EL, Friebel TM, Cronin A, Leslie G, McGuffog L, Adlard J, Agata S, Agnarsson BA, Ahmed M, Aittomaki K, Alducci E, Andrulis IL, Arason A, Arnold N, Artioli G, Arver B, Auber B, Azzollini J, Balmana J, Barkardottir RB, Barnes DR, Barroso A, Barrowdale D, Belotti M, Benitez J, Bertelsen B, Blok MJ, Bodrogi I, Bonadona V, Bonanni B, Bondavalli D, Boonen SE, Borde J, Borg A, Bradbury AR, Brady A, Brewer C, Brunet J, Buecher B, Buys SS, Cabezas-Camarero S, Caldes T, Caliebe A, Caligo MA, Calvello M, Campbell IG, Carnevali I, Carrasco E, Chan TL, Chu ATW, Chung WK, Claes KBM, Collaborators GS, Collaborators E, Cook J, Cortesi L, Couch FJ, Daly MB, Damante G, Darder E, Davidson R, de la Hoya M, Puppa LD, Dennis J, Diez O, Ding YC, Ditsch N, Domchek SM, Donaldson A, Dworniczak B, Easton DF, Eccles DM, Eeles RA, Ehrencrona H, Ejlertsen B, Engel C, Evans DG, Faivre L, Faust U, Feliubadalo L, Foretova L, Fostira F, Fountzilas G, Frost D, Garcia-Barberan V, Garre P, Gauthier-Villars M, Geczi L, Gehrig A, Gerdes AM, Gesta P, Giannini G, Glendon G, Godwin AK, Goldgar DE, Greene MH, GutierrezBarrera AM, Hahnen E, Hamann U, Hauke J, Herold N, Hogervorst FBL, Honisch E, Hopper JL, Hulick PJ, Investigators $\mathrm{K}$, Investigators $\mathrm{H}$, Izatt L, Jager A, James $\mathrm{P}$, Janavicius $\mathrm{R}$, Jensen UB, Jensen TD, Johannsson OT, John EM, Joseph V, Kang E, Kast K, Kiiski JI, Kim SW, Kim Z, Ko KP, Konstantopoulou I, Kramer G, Krogh L, Kruse TA, Kwong A, Larsen M, Lasset C, Lautrup C, Lazaro C, Lee J, Lee JW, Lee MH, Lemke J, Lesueur F, Liljegren A, Lindblom A, Llovet P, Lopez-Fernandez A, Lopez-Perolio I, Lorca V, Loud JT, Ma ESK, Mai PL, Manoukian S, Mari V, Martin L, Matricardi L, Mebirouk N, Medici V, Meijers-Heijboer HEJ, Meindl A, Mensenkamp AR, Miller C, Gomes DM, Montagna M, Mooij TM, Moserle L, Mouret-Fourme E, Mulligan AM, Nathanson KL, Navratilova M, Nevanlinna H, Niederacher D, Nielsen FCC, Nikitina-Zake L, 
Offit K, Olah E, Olopade OI, Ong KR, Osorio A, Ott CE, Palli D, Park SK, Parsons MT, Pedersen IS, Peissel B, Peixoto A, Perez-Segura P, Peterlongo P, Petersen AH, Porteous ME, Pujana MA, Radice P, Ramser J, Rantala J, Rashid MU, Rhiem K, Rizzolo P, Robson ME, Rookus MA, Rossing CM, Ruddy KJ, Santos C, Saule C, Scarpitta R, Schmutzler RK, Schuster H, Senter L, Seynaeve CM, Shah PD, Sharma P, Shin VY, Silvestri V, Simard J, Singer CF, Skytte AB, Snape K, Solano AR, Soucy P, Southey MC, Spurdle AB, Steele L, Steinemann D, Stoppa-Lyonnet D, Stradella A, Sunde L, Sutter C, Tan YY, Teixeira MR, Teo SH, Thomassen M, Tibiletti MG, Tischkowitz M, Tognazzo S, Toland AE, Tommasi S, Torres D, Toss A, Trainer $A H$, Tung $N$, van Asperen $C J$, van der Baan FH, van der Kolk LE, van der Luijt RB, van Hest $L P$, Varesco $L$, Varon-Mateeva $R$, Viel A, Vierstraete J, Villa $R$, von Wachenfeldt A, Wagner $P$, Wang-Gohrke $S$, Wappenschmidt B, Weitzel JN, Wieme G, Yadav S, Yannoukakos D, Yoon SY, Zanzottera C, Zorn KK, D'Amico AV, Freedman ML, Pomerantz MM, Chenevix-Trench G, Antoniou AC, Neuhausen SL, Ottini L, Nielsen HR, Rebbeck TR: Association of Genomic Domains in BRCA1 and BRCA2 with Prostate Cancer Risk and Aggressiveness. Cancer Res 2020, 80:624-38.

[57] Munkley J, Livermore KE, McClurg UL, Kalna G, Knight B, McCullagh P, McGrath J, Crundwell M, Leung HY, Robson CN, Harries LW, Rajan P, Elliott DJ: The PI3K regulatory subunit gene PIK3R1 is under direct control of androgens and repressed in prostate cancer cells. Oncoscience 2015, 2:755-64.

[58] Yang R, Du Y, Wang L, Chen Z, Liu X: Weighted gene co-expression network analysis identifies CCNA2 as a treatment target of prostate cancer through inhibiting cell cycle. J Cancer 2020, 11:1203-11.

[59] Yang X, Ye C, Zheng H, Dai C, Zhu Y: Systemic Analyses of the Expression of TPI1 and Its Associations with Tumor Microenvironment in Lung Adenocarcinoma and Squamous Cell Carcinoma. Dis Markers 2022, 2022:6258268.

[60] Ifere GO, Desmond R, Demark-Wahnefried W, Nagy TR: Apolipoprotein E gene polymorphism influences aggressive behavior in prostate cancer cells by deregulating cholesterol homeostasis. Int $J$ Oncol 2013, 43:1002-10.

[61] Luo F, Wang YZ, Lin D, Li J, Yang K: Exonuclease 1 expression is associated with clinical progression, metastasis, and survival prognosis of prostate cancer. J Cell Biochem 2019. 